\title{
Truth and Lies in the Stravinskyan Sense: Oedipus Rex
}

\section{Citation}

Albright, Daniel. 2007. Truth and lies in the Stravinskyan sense: Oedipus Rex. Modernist Cultures 3(1): 26-32.

\section{Published Version}

http://www.eupjournals.com/journal/mod;http://www.js-modcult.bham.ac.uk/backissues.asp? issue $=26 \&$ issue_name $=$ Volume $+3 \% 2 C+$ Issue $+1+\% 28$ Winter $+2007 \% 29$

\section{Permanent link}

http://nrs.harvard.edu/urn-3:HUL.InstRepos:3356137

\section{Terms of Use}

This article was downloaded from Harvard University's DASH repository, and is made available under the terms and conditions applicable to Other Posted Material, as set forth at http:// nrs.harvard.edu/urn-3:HUL.InstRepos:dash.current.terms-of-use\#LAA

\section{Share Your Story}

The Harvard community has made this article openly available.

Please share how this access benefits you. Submit a story.

Accessibility 


\title{
Truth and Lies in the Stravinskyan Sense: Oedipus Rex
}

\author{
Daniel Albright
}

Among the modernists, most treatments of Sophocles felt the weight of Nietzsche's The Birth of Tragedy, especially treatments of Oedipus Rex, since Nietzsche (like Aristotle himself) treated Sophocles's play as something like the ideal specimen Greek drama: Oedipus blinded himself after gazing into the pit, facing the intolerable truth not just about his own parentage but about all human life - better never to have been born. Stravinsky, with his brightly-outlined formal designs and sec textures, is often considered the most Apollonian of composers: a lover of music-boxes and clockwork. But in Oedipus Rex Stravinsky confronts Dionysus, Nietzsche's Dionysus. Stravinsky conceived his art in Nietzschean terms, as a struggle between Dionysus and Apollo, as he (or his ghostwriter Alexis Roland-Manuel) said in a 1939 Harvard lecture printed in Poetics of Music:

What is important for the lucid ordering of the work - for its crystallization - is that all the Dionysian elements which set the imagination of the artist in motion and make the life-sap rise must be properly subjugated before they intoxicate us, and must finally be made to submit to the law: Apollo demands it. $^{1}$

In a sense Oedipus Rex (like all of Stravinsky's work) is a play about Dionysus Chained; it is as if Euripides' Bacchae were rewritten to show King Pentheus triumphant over the subjugated body of the god. And yet it's not quite certain whether the subjugating energy is truly Apollo's - perhaps it comes from Dionysus in another guise.

Nietzsche conceived the music of the abyss along Wagnerian lines: beneath the mind's categories of time and space, beneath all the precisions and divisions that articulate our vision of reality, there lies a delirium, a vertigo, a void, a plenum. The prelude to Tristan, with its long reeling from one key to another, seemed a good musical image for this state. Stravinsky, however, had no interest whatsoever in smears and blurs; on the other hand the notion of music as a kind of torture device, a machine for pounding, crushing, dismembering, interested him a good deal. Stravinsky's way of attacking the concept of the human subject - and Nietzsche's early philosophy is one long attack on the human subject - is entirely of the twentieth century: through motordriven devices, mechanical warfare, not through Wagnerian exercises in drowning.

Stravinsky's Oedipus Rex is a death-haunted work. Now this could be said about Sophocles's version, or anybody's version, but Stravinsky extends the idea of deathliness in all sorts of strange directions. Sophocles has Jocasta hang herself; but Stravinsky, a more flagrant sort of mass murderer, kills off the language, the music, even the concept of drama itself. Cocteau's narrator says that Oedipus contends with "those deities who watch us from beyond death" (i): and Oedipus Rex is indeed a post-mortem opera, a sort of autopsy of a Greek tragedy. ${ }^{2}$

First, it is important to note that the text is in Latin. Why Latin? Sophocles wrote in Greek, and Stravinsky didn't imagine that performances of his work should be confined to the Vatican. Stravinsky gave several reasons for this peculiar choice: he said that the inspiration for the work was his discovery in September 1925 of a biography of Francis of Assisi, who spoke Italian, but prayed in "hieratic" Provençal, a "sacred language." The notion of detaching language from normal speech, perhaps from any sort of speech, so that it would seem inscriptive, gashed, a kind of writing-for-the-ear, intrigued him. Stravinsky also said that the music was composed during his "strictest and most earnest period of Christian orthodoxy," and wanted to "use the language that is also the language of the Western Church . . . I chose the archetypal drama of purification."3 This doesn't mean that Stravinsky understood Oedipus Rex as a deflection of the eucharist in the world of Greek tragedy; it means only that a work in an extraordinarily strict style was congruent formally to the strictness of his Christian beliefs. Stravinsky remarked that religion "does not correspond in my mind to states of feeling or sentiment, but to dogmatic beliefs” (Dialogues, 26). Stravinsky's Oedipus Rex isn't Christian, but rigidity and dogma are properties that everyone can hear in it. Another reason for Stravinsky's choice of Latin was that he wanted a text that could be heard purely as phonetic, that is, musical, material; by 
Albright, 'Truth and Lies in the Stravinskyan Sense'

writing in a language that few listeners could understand, he minimized the troublesome and distracting semantic elements of language: as he put it, "When I work with words in music, my musical saliva is set in motion by the sounds and rhythms of the words" (Dialogues, 22). For all that, sometimes the Latin text is extremely effective on a semantic level: for example, the chorus sings "Reskiturus sum monstrum, monstrum reskiscam, Deo claro Oedipus natus est" " I am soon to discover a wonder; Oedipus is born of a god] (69-70); but after Oedipus's fall the chorus sings “Ekke! Regem Oedipoda: foedissimum monstrum monstrat” [Behold! King Oedipus; he shows a most foul monster] (93) - the progress from monstrum meaning wonder to monstrum meaning monster summarizes the play's whole development in a single pun, a pun possible only in Jean Daniélou's Latin, not Cocteau's French. ${ }^{4}$

So Stravinsky investigated the world beyond death by using a dead language. But Latin isn't the only dead language present here: Stravinsky uses extinct musical means as well. To understand Stravinsky's situation in 1927, we must go back a few years to certain events in Germany. Around 1923, Schoenberg told some friends that he had made a discovery that would ensure the supremacy of German music for the next hundred years. This discovery was the twelve-tone method. This was a procedure that removed from music all possibility of a tonic note, of a key, by a legislative act: the basis of a musical composition would no longer be a scale but a tone row. A tone row is an ordered set of the twelve notes of the chromatic scale; this set is the quarry from which all melody and harmony are drawn. This method gives an absolute equality to each of the twelve notes, since you can't give any priority to one note - you can't interrupt the tone row to insert a second E-flat once you've heard the first E-flat. There are ways around this rule, since you can group notes from the row into chords at pleasure, and thus make some notes stand out while others are suppressed; but the twelve-tone method is nonetheless intended as a decisive defeat of the principle of tonality, while nevertheless preserving something of the orderliness, the rigor, of the tonal system. This method could be used for many purposes, even comic opera, but was especially well-adapted to Neoclassical procedures, as many of Schoenberg's earliest twelve-tone works showed: for instance, the gavotte in the Piano Suite sounds like a sort of music-box for mechanical grasshoppers. Schoenberg himself did not announce that tonal music was henceforth dead, but some of his pupils, such as Anton Webern, were quite willing to make that leap.

Stravinsky was conscious that he came from Russia, no great musical center: "I am a double émigré, born to a minor musical tradition and twice transplanted to other minor ones [the French and the American]" (Dialogues, 27); for this reason he was uneasy about his relation to the Western mainstream, namely German music. I suspect in the late 1920s he was especially uneasy: if tonal music was dead, and if Stravinsky wrote tonal music, what did this mean about Stravinsky's place in musical history? Late in life Stravinsky remarked, recollecting Schoenberg's cold responses to Oedipus Rex:

I know that the Oedipus music is valued at about zero by present progressive-evolutionary standards, but I think it may last awhile in spite of that. I know too that I relate only from an angle to the German stem(Bach-Haydn-Mozart-Beethoven-Schubert-Brahms-Wagner-Mahler-Schoenberg), which evaluates largely in terms of where a thing comes from and where it is going. But an angle may be an advantage. (Dialogues, 30)

My guess is that Stravinsky in 1927 wanted to use his foreignness, his off-at-an-angledness, his estrangement from the grand German tradition, to his advantage. He spoke mainstream Western music, one might say, with a funny accent; he knew it as one knows a dead or dying language. Even in Pulcinella, seven years before, Stravinsky had a certain aspect of Dr. Frankenstein, reviving the corpse of dead music by means of jolts of electricity; and Oedipus Rex is a whole zombie opera: I see dead music walking. The early reviews were generally bad: critics complained (the reviews still stung Stravinsky after decades) that the composer of Petrushka was stooping to a pastiche of Handel, that the music for Creon's aria was a march straight out of Meyerbeer, etc. There's little direct quoting of old music, but many listeners have the impression that Stravinsky is digging up fossils and plastering the bones together every which way: a Tyrannosaurus skull here, a tusk of a Mastodon there, an Archaeopteryx wing sticking straight up. Stravinsky cheerfully admitted this: 
Modernist Cultures, 3(1)

I do not now recall any predatory attractions to other composers at the time, though, if another composer is suggested in my score, he is Verdi. Much of the music is a Merzbild, put together from whatever came to hand. I mean, for example ... the fusion of such widely divergent types of music as the Folies Bergères tune at No. 40 ('The girls enter, kicking') and the Wagnerian 7th-chords at Nos. 58 and 74. I have made these bits and snatches my own, I think, and of them a unity. (Dialogues, 27)

Schwitters's word Merzbild, a nonsensical term for a nonsense-collage, is a bit disconcerting here, since one doesn't usually think of Stravinsky as a Dadaist. But Dada is as good as any way of imaging the abyss; and Stravinsky's way of dealing with Dionysus is to negate his material via Dada procedures. Devices, little tricks of music drama from Gluck, Verdi, Handel, everyone you can think of, are picked up with tweezers and glued together. The devices themselves may be dead, but jammed together at odd angles they come to life, just as used ticket stubs and gum wrappers grow vivid in Schwitters's Merzbilder.

Every experienced listener who hears Oedipus Rex picks up a bone or two and identifies its source reptile. Leonard Bernstein, in his famous 1972 Norton lectures at Harvard, explains how he drove himself mad trying to figure out what the opening chorus reminded him of; eventually the solution of the riddle finally came to him: the little phrase pieta ti prendi [take pity, I love him too, but you are powerful] that the supplicant Aïda sings to Amneris in Verdi's opera. I myself was driven mad by an excited passage in the Oedipus-Jocasta duet Oracula mentiuntur [oracles lie] (56) - a descending tangle of notes - until I finally figured out that I was hearing in the distant background a phrase that Iago sings in Verdi's Otello: Questa e una ragna [the handkerchief is the spider]. You can always find a reason for Stravinsky's cooption: Bernstein explains his eureka as follows: "the whole metaphor of pity and power came clear: the pitiful Thebans supplicating before their powerful king, imploring deliverance from the plague. Pity and power: an Ethiopian slave girl at the feet of her mistress, Princess of Egypt." ${ }^{5}$ And I could connect Oedipus to Iago: the music is itself the snare, the spider's web, in which Oedipus or Othello is caught: it has a sort of winding quality to it, as if melodic loops were catching up arms and legs. But the very multiplicity of these connections of the score to Verdi and all the other music dramatists makes them fragile: Stravinsky is using the stuff of high music drama, but in a way that reminds us that this stuff is splendid but passé; Oedipus Rex is a kind of tombstone over the whole genre of opera. It contains the whole repertoire while standing apart from it.

If Oedipus Rex is dead music ornamenting a dead language, it follows that it might well wish to kill off the notion of drama as well. The dramaturgy is quite peculiar, as Stravinsky explains:

No one 'acts,' and the only individual who moves at all is the narrator, and he merely to show his detachment from the other stage figures. Oedipus Rex . . . is not at all operatic in the sense of movement. The people in the play . . . do not turn to listen to each other's speeches, but address themselves directly to the audience. I thought they should stand rigidly, and in my original version I did not even allow them exits and entrances. My first conception was that the people of the play should be revealed from behind small individual curtains, but I realized later that the same effect might be accomplished more easily by lighting . . . the singers should be illuminated during their arias and become vocally, though not physically, animated statues. Oedipus himself should stand in full view throughout, of course, except after the 'Lux facta est,' when he must change masks [. . .] I am often asked why I should have tried to compose a waxworks opera. (Dialogues, 23-24)

The notion of a stage fractured into a number of private mini-stages, each inhabited by one character, suggests just how far Stravinsky was willing to go toward a Cubist tessellation of the concept of drama: he happily dismembered the stage, just as his music sometimes seems to tear the characters limb from limb.

Stravinsky's favorite staging of Oedipus Rex was Cocteau's 1952 production, and there is reason to believe that if Cocteau had been in charge of the 1927 premiere, it would have resembled what he did in 1952. Stravinsky particularly liked Cocteau's "huge masks" (Dialogues, 25). Cocteau's mask of the blinded Oedipus as a human lobster, with eyes at the end of stalks spouting ropes of blood, may well have appealed to Stravinsky's dramacidal lust: Sophocles demoted to the crustacean level. Cocteau, left to his own devices, tended to be frivolous about Greek drama; a few years after Oedipus Rex he wrote another play on the same 
Albright, 'Truth and Lies in the Stravinskyan Sense'

theme, The Infernal Machine, where the sphinx is a flirtatious femme fatale with long gloves à la Marlene Dietrich, and Jocasta is a giggly young widow who pouts to Tiresias (whom she nicknames Zizi) that it isn't fair that all the other girls get to go to dances, while she has to be in mourning. This sort of frivolity had no attraction for Stravinsky; yet Stravinsky too fools around in the musical margins of the drama, while taking care that Dadaist hysteria doesn't destroy the impression of statue-like rigor and monumentality. Cocteau once wrote a poem to Stravinsky that contained the line "Je sculpte en rêve Igor ton audible statue" [dreaming I sculpt Igor your audible statue]; and the whole of Oedipus Rex is indeed a speaking statue, impressive yet bizarre - a talking classical marble isn't far from that talking life-sized statue of Abraham Lincoln that used to be at Disneyland.

Now that we've looked at a number of forms of deadness clustered around Oedipus Rex, it's time to look at some of its sources of life. Life in music tends to arise from dialectic, and the main dialectic of Stravinsky's music is a simple antithesis: power vs. pity, as Bernstein puts it (The Unanswered Question, 411), or as Aristotle would put it, terror vs. pity. The opera opens with a loud five-note theme, B-flat - C - A - B-flat A, followed by the soft declaration Theba peste moritur [Thebes is dying of plague] (1); then the loud music returns; and then a soft passage repeating the name Oedipus over groups of three eighth-notes bouncing between the notes B-flat and D. Soft pleas for pity are sandwiched between stark implacable musical figures; and this sense of pity trying to find some room for expression between hard slabs of music is part of the generating dialectic of the play. Often the pity-music is formed in $6 / 8$, out of those bouncing groups of three eighth-notes. Stravinsky wrote "All of my 'ideas' for Oedipus Rex were in one sense derived from what I call the versification" (Dialogues, 28) - in other words, from the metrical patterns of Greek poetry. Now one of the basic Greek meters is the dactyl, long-short-short; and the groups of three eighth-notes (bum-bum-bumBUM-BUM-BUM) seems a sort of continual allusion to the meters of classical poetry, even though Stravinsky pays no attention to the actual scansion of the words, which he misconstrues in every way possible; for example in the second soft part of the opening, the chorus sings OE-DI-pus, oe-DI-pus, casually shifting the syllable-length and the accent. Perhaps the most metrically intense passage in the chorus is the prayer to Apollo, Delie exspectamus [We await you, Delian] (27): there is a sort of fatal dactylic underrhythm beneath every choral plea: their desires are everywhere constrained by hard metrical facts that can't be evaded, no matter how strong their pleas for leniency.

The music that Stravinsky assigned to the soloists is governed by a similar dialectic, that of truth vs. falsehood. Creon enters to a striking figure, singing "Respondit deus" [the god answers] (15). What does the god say? Perhaps that matters less than how the god says it, in a descending $C$ major triad. This sort of ultrasimple figure represents Authority. Creon freely tells everything he knows; then Tiresias enters, "the fountain of truth" as the narrator calls him, knowing a great deal more, but refusing to speak: "Dikere non possum" [I cannot say] (32). Most of the accompaniment here consists of empty octaves; and soon Tiresias sings another falling triad, this time in E minor. Truth, whether spoken or tacit, seems to be triadic in nature. When, in the second act, the Messenger at last announces the Truth, the horrible Truth - Polybus was not Oedipus's father - he sings it to a descending major scale: "non genitor Oedipodis" [not the father of Oedipus] (66-67). Nothing but a falling major scale: triads, scales, the rudiments that support tonal music, whether tonal music lies in its grave or still retains some force; these are the strong Doric columns that support the temple of the gods. The notion that divine authority is best expressed by a falling, perhaps a smiting, scale is part of the old stock and trade of opera and oratorio composers: in Athalia (1733) Handel provides for Abner an aria on God's majesty, When storms the proud to terrors doom, in which one of the most salient phrases is a falling scale; and in Wagner's Der Ring des Nibelungen, Wotan's authority is grounded on the runes carved in his spear - and the Leitmotiv of the spear is a falling scale.

Inauthenticity is of course represented by music that is exactly opposite in character: shifty, florid music. At Oedipus's first entry he sings "Liberi, vos liberabo" (9) - just as I saved you from the sphinx I will save you from the plague. Stravinsky referred to this as Oedipus's spreading "the tail feathers of his pride" (Dialogues, 28), and it is indeed preening, peacocky music. Show-off music requires the techniques of eighteenth-century opera, such as Handel's, the sort of opera designed for singers to display brilliant roulades, the whole battery of coloratura. I think it's significant that Stravinsky accompanies this opening aria with the iambic figures in the orchestra: the iamb is satirical meter in classical poetry; in fact the word iamb is derived 
Modernist Cultures, 3(1)

from the verb wound, and its skipping, short-long rhythm has a limping gate. As we know, the name Oedipus means in Greek swollen foot and Oedipus's music often has a hobbly sort of gait to it. And much of the orchestration of Liberi, vos liberabo is for winds, providing the accompaniment with a snide, snarky feel, as if the orchestra were sticking up its nose.

Another sort of inauthenticity can be found in Jocasta's music, in her famous aria Nonne erubescite. This is some of the most Merzbildlich music in the score. Bernstein took special glee in describing it as "a hoochykoochy dance” (Bernstein, 399), and that sounds just about right: belly-dance, strip-tease, any sort of hokey, chromatic, fake-Oriental scene you want to imagine. The sheer wrongness of the music for the text is Stravinsky's way of telling us that Jocasta, like Oedipus, lives in an unreal world, a fool's world. She keeps telling us that oracles can lie; but the only lies we hear are those coming from her mouth. She is a stock caricature of Woman as seductress, temporizer, nurse, just as Oedipus is a stock caricature of Man as arrogant vainglorious problem-solver: don't you fret, little Thebans, I'll take care of everything.

The score is as consistently excellent as anything in twentieth-century music, but the last ten minutes are remarkable even by Stravinsky's standards. When Oedipus is dazzled by the final revelation, his Handelian boasting vanishes utterly:
Natus sum quo nefastum est,
[I was born from one who should not have given birth, Concubui cui nefastum est, I married one whom I should not have married, Kekidi quem nefastum est. Lux facta est. I killed one whom I should not have killed. Light dawns.] (79)

Pride goeth before a fall, and this is the fall: a descending B minor triad in the vocal line moving toward a conclusive D major resolution in the orchestra. Now, for the first time, Oedipus gets truth-music, of the sort that Creon and Tiresias and the Messenger sang earlier; but it is a truth that destroys. The final chorus returns to the mode of the opening chorus, in which terror keeps hemming in, circumscribing any possibility of pity: the Messenger keeps repeating his "four-word singing telegram" (Dialogues, 30) "Divum Jocastae caput mortuum" [the divine head of Jocasta is dead] (58), while the chorus tells of Jocasta's suicide and Oedipus's self-mutilation.

Opera composers learned a long time ago that tragedy can best be expressed by a sort of refrain structure in which pity and terror alternate. The first tragedy in Western music that found a strikingly effective way of accomplishing this was Gluck's Orfeo ed Euridice (1762), in the scene in hell, when the Furies shout to Orpheus to go back, but he pleads with them to let him enter, so that he can rescue Euridice from the underworld. Stravinsky's scene follows this model exactly, but backwards: the soloist represents the inflexible boundary, and the chorus is the oppressed human presence that tries to cross it. The Messenger's great cry becomes a sort of hieroglyph of fate; between its inexorable call, the chorus keeps pushing out for room, a little bit, then a little harder, but finally collapses. It's the musical equivalent of the walls in the famous room in Poe's "The Pit and the Pendulum" that keep getting closer and closer together, squeezing the occupant. Stravinsky called this chorus, quite wonderfully, a "mortuary tarantella" (Dialogues, 29). The notion of dancing this hectic cheerful rhythm in a morgue is another example of Stravinsky's clowning with expressiontropes at the margins of the sober text - just as he dressed Jocasta in the musical equivalent of harem pants earlier. But the tarantella was so named after the Italian word for tarantula - the purpose of the frenzied spasms was to rid the body of venom. The plague that infects Thebes infects the rhythm of the chorus as well, until the whole thing leaves off: "Vale, Oedipus, te amabam" [Farewell, Oedipus, we loved you] (95) - in the bouncing dactyls so often heard before. It is as if the opera trails away into a sort of empty meter, a surface on which a poet might inscribe a song if there were anything left to sing.

Oedipus Rex was intended as a birthday gift for Diaghilev, but the great impresario didn’t much like it, and it had trouble finding its way into the twentieth-century canon. Those who hated Stravinsky - and incomparably the most talented hater of Stravinsky was Theodor Adorno - found in his works of the late 1920s fresh ammunition to be used against him. In the course of his astonishing book Philosophy of Modern Music, Adorno uses Stravinsky as a rag to shine Schoenberg's shoes - Adorno calls Stravinsky an acrobat, a civil servant, a tailor's dummy, hebephrenic, psychotic, infantile, fascistic, and devoted to making money. But 
Albright, 'Truth and Lies in the Stravinskyan Sense'

there's one comment of Adorno's that I think goes far toward elucidating just what Oedipus Rex is: “The completely shrewd, illusionless I exalts the Not-I as an idol"; a work by Stravinsky "maliciously bows to the public, takes off its mask, and shows that there is no face under it, only a knob." If you think of Oedipus Rex as an idol, a Greek statue that takes off its mask and shows only a knob, it makes perfect sense, though one needn't find it quite so troubling as Adorno does.

What could Adorno have been thinking of when he compared a work by Stravinsky to a knob beneath a mask? I suspect he must have been thinking of the paintings of Giorgio de Chirico, such as The Disturbing Muses (1925), in which a red balloon is perched on top of a togated torso, itself mounted on a column. The notion of an effaced, worn-away classicism, in which the heads of statues have eroded into punching bags or the balls on top of banisters, and the lucid space has cracked apart into competing systems of perspectives - it all seems perfectly appropriate for Stravinsky's Oedipus Rex, with its systems of competing mini-stages, and its oddly stylized, evacuated protagonists. The same year that Oedipus Rex appeared, 1927, Chirico painted The Archaeologists, in which the knob-headed archaeologists have fragments of classical antiquity tucked away inside their torsos. This is exactly how Adorno understood Stravinsky: an inhuman presence, contemptuous and contemptible, displaying the splinters and shards and broken pedestals he had scavenged from Handel and Verdi and other great composers of the past. Another gifted writer on music, the composer Ernst Krenek, explicitly compared Stravinsky's Oedipus Rex to the paintings of Chirico:

The classicism of antiquity in Oedipus Rex is just as problematic as de Chirico's landscape of ruins ... What is brought to light here looks more like excavations after an earthquake than like something freshly copied out of the atelier. Everything questionable in the age is engraved on the smooth façades erected here; and the ground, that bears the weight of the whole splendor, is furrowed by many uncanny rifts and fissures. The classicism of antiquity lives here anew and in the same shape in which it genuinely came to us: in the form of fragments. The torso, mutilated by invisible forces, has a more mysteriously intense and charged life than the whole that it perhaps once was; in Neoclassicism (distinguished from the Renaissance in that it falls short of perfection because it lacks any intention for wholeness and illusion), the scars and fractures that a work carries with or without the intention of the maker, are not only its charm, but also represent its sole truth [. . .] In the domain of the fragmentary the development of Neoclassicism is connected with Surrealism, which, more energetically destructive, lives in the montage of the ruins that it comes across. ${ }^{7}$

Krenek understood Surrealism and Neoclassicism as roughly the same thing, a way of re-using the past, not for the sake of glorifying the achievement of the past, not for the sake of aligning the present with the high standards of the past, but for the sake of flaunting in your face the degradation of the past, the pastness of the past. How can one demonstrate destructive energy? By displaying a destroyed thing. The Venus de Milo is exciting because she has lost her arms: we are all caught up in force fields that extinguish, snap off, stub out, rub away, and Surrealist art sets itself the challenge of exhibiting these force fields. Surrealism, to Krenek, is simply entropy in visual plastic. It follows that Oedipus Rex, like The Waste Land, offers us pre-decayed materials, flitters and rubble - for the only way to be truthful to the past is to recognize its lack of integrity.

\section{Notes}

${ }^{1}$ Igor Stravinsky, Poetics of Music (Cambridge: Harvard University Press, 1970), 80-81.

${ }^{2}$ All references are to Igor Stravinsky, Oedipus Rex: Opéra-Oratorie en deux actes, d' après Sophocle, par Igor Stravinsky et Jean Cocteau. Nouvelle Réduction pour chant et piano par L'auteur. Editions Russe de Musique (Paris: S. et N. Koussewizky [Boosey \& Hawkes], 1949).

${ }^{3}$ Igor Stravinsky and Robert Craft, Dialogues (Berkeley: University of California Press, 1982), 21; 26. Subsequently cited parenthetically as Dialogues. 
${ }^{4}$ In some instances, Stravinsky changed the Latin "c" to a "k" as a pronunciation guide.

${ }^{5}$ Leonard Bernstein, The Unanswered Question (Cambridge: Harvard University Press, 1976), 411.

${ }^{6}$ Theodor Adorno, Philosophie der neuen Musik (Frankfurt: Europäische Verlagsanstalt, 1966), 159.

${ }^{7}$ Quoted in Daniel Albright, Modernism and Music (Chicago: University of Chicago Press, 2004), 332-33. 